\title{
The androgen receptor inhibits transcription of GPER1 by preventing Sp1 and Sp3 from binding to the promoters in prostate cancer cells
}

\author{
Austin McDermott ${ }^{1}$, KyoungHyun Kim¹, Susan Kasper ${ }^{1}$, Shuk-Mei Ho ${ }^{1,2,3}$ and Yuet- \\ Kin Leung ${ }^{1,2,3}$ \\ ${ }^{1}$ Department of Environmental Public Health Sciences, College of Medicine, University of Cincinnati, Cincinnati, OH 45267, USA \\ ${ }^{2}$ Central Arkansas Veterans Healthcare System, Little Rock, AR 72205, USA \\ ${ }^{3}$ Department of Pharmacology and Toxicology, College of Medicine, University of Arkansas for Medical Sciences, Little Rock, \\ AR 72205, USA \\ Correspondence to: Yuet-Kin Leung, email: rickyleung@uams.edu \\ Shuk-Mei Ho, email: shukmeiho@uams.edu \\ Keywords: GPR30; castration resistant; promoter; GPER1 spliced variants; transcription start site \\ Received: October 18,2021 Accepted: December 08, $2021 \quad$ Published: January 07, 2022
}

Copyright: @ 2022 McDermott et al. This is an open access article distributed under the terms of the Creative Commons Attribution License (CC BY 3.0), which permits unrestricted use, distribution, and reproduction in any medium, provided the original author and source are credited.

\section{ABSTRACT}

G-1, a GPER1 agonist, was shown to inhibit the growth of castration-resistant mouse xenografts but not their parental androgen-dependent tumors. It is currently unknown how the androgen receptor (AR) represses GPER1 expression. Here, we found that two GPER1 mRNA variants (GPER1v2 and GPER1v4) were transcriptionally repressed, not via transcript destabilization, by the androgen-activated AR. Although no AR binding was found in all active promoters near GPER1, data from promoter assays suggested that both variants' promoters were inhibited by androgen treatment. Site-directed mutagenesis on $\mathrm{Sp1/Sp3} \mathrm{binding} \mathrm{sites} \mathrm{revealed} \mathrm{their} \mathrm{role}$ in supporting the basal expression of GPER1. Knockdown of Sp1 and Sp3 together but not separately repressed GPER1 expression whereas overexpression of both Sp1 and Sp3 together was required to alleviate AR repression of GPER1. Based on the chromatin immunoprecipitation data, Sp3 was found to bind to the promoters prior to the binding of Sp1 and RNA polymerase II. However, the binding of all three transcription factors was inhibited by DHT treatment. Concordantly, DHT treatment induced nuclear interactions between AR and Sp1 or Sp3. Taken together, these results indicate that AR represses transcription of GPER1 by binding to Sp1 and Sp3 independently to prevent their transactivation of the GPER1 promoters.

\section{INTRODUCTION}

Therapies that target the activity of the androgen receptor (AR) remain central to the treatment of prostate cancer (PCa), as AR signaling is known to be a primary factor for driving $\mathrm{PCa}$ growth, progression, and metastasis [1]. Although androgen deprivation therapies (ADT) are effective and remain a common treatment for patients, castration resistant PCa (CRPC) inevitably develops as both epigenetic and genetic alterations allow the PCa to bypass therapeutic interventions. Therefore, many studies have focused on how AR is overexpressed, modified by mutation, or differentially spliced to drive the AR signaling axis under ADT and promote cancer growth
$[2,3]$. While the clinical significance of AR mediated gene activation in PCa has been widely reported, for example overexpression of the TMPRSS2-ERG fusion gene, there is considerably less attention paid to the AR as a direct transcriptional repressor and how this role is implicated in $\mathrm{PCa}$ progression. As the AR has been reported to repress both PCa tumor suppressor genes [4-7] and oncogenes [810], a deeper understanding of AR-mediated suppression will be vital to the development of future therapeutics which prevent the emergence of CRPC.

In addition to targeting AR activity, it has long been known that estrogens are highly effective at treating advanced $\mathrm{PCa}$ [11]. Despite associated cardiovascular toxicity initially limiting their clinical 
use $[11,12]$, both estrogen $[13,14]$ and diethylstilbestrol $[15,16]$ have recently been re-investigated in $\mathrm{PCa}$ treatment. The tumor suppressive effects of estrogens were originally thought to be facilitated by estrogen receptors ER $\alpha$ and ER $\beta$, but recent research from our lab has identified a third ER, G-protein Estrogen Receptor 1 (GPER1), that plays a critical role in suppressing PCa growth [17]. Specific activation GPER1 by the drug G-1 (1(1-[4-(6-bromobenzo[1,3]dioxol-5-yl)-3a,4,5,9btetrahydro-3H-cyclopenta[c]quinolin-8-yl]-ethanone) inhibited tumor growth and led to $60 \%$ necrosis of CRPC LNCaP-derived xenografts in castrated mice [17]. Interestingly, G-1, a GPER1 agonist, showed no effect in the parental androgen-dependent PCa of non-castrated mice [17]. Cell-based analyses revealed this discrepancy could be due to the ligand-bound AR repressing GPER1 expression.

AR mediated gene repression includes both nongenomic and genomic mechanisms. Non-genomic mechanisms occur seconds to minutes after activation and include the modulation of protein kinase pathways (such as activation of Src [18]) and reduced nuclear localization of transcription factors (TFs) (such as RelA [19]). On the genomic side, androgen bound AR has been shown to bind to promoters or distal enhancers often $>10 \mathrm{~kb}$ away and recruit repressive complexes consisting of EZH2 [20], LSD1 [21], and HDACs [8]. Other genomic mechanisms of repression which do not involve DNA binding are competition of cofactors and direct inhibition of TFs. An example of the former includes NF-KB which competes with AR for CREB binding protein [19]. TFs inhibited by AR include Runx2 [22], SF-1 [23], ATF-2 [24], and Smad3 [25]; however, Sp1 is the most studied factor in AR dependent gene repression [8, 26-32]. Sp1 is generally involved in gene activation through its transactivation domain by binding to promoters or enhancers [33] although it can act as a repressor [34-36].

In the presence of androgens, the $\mathrm{AR}$ binds free floating (but not DNA bound) Sp1 as shown in gel shift assays, and this interaction requires the AR DNA binding domain [27, 29]. Similar results have been reported from Glutathione-S-transferase pull-down assays [37]; Sp1, $\mathrm{Sp} 3$, and $\mathrm{Sp} 4$ are conserved Sp/XKLF members which recognize the same GC- and GT- boxes with nearly the same affinity [38, 39]. Sp3 can act as an activator or repressor [40]. Normally, Sp1 and Sp3 are ubiquitously expressed in cells, and $\mathrm{Sp} 4$ expression is restricted to neuronal cells where it acts as a transcription activator [41-43]; however, Sp4 expression has been found in many cancer cell lines such as the LNCaP $[44,45]$. Neither Sp3 nor $\mathrm{Sp} 4$ have been implicated in AR mediated repression before.

This study aimed to determine the mechanism of how AR represses GPER1 and thereby by-passes the tumor suppressive action of G-1 treatment in CRPC. Understanding this underlying mechanism would allow us to better design more effective strategies for targeting the AR in both primary PCa and CRPC patients.

\section{RESULTS}

\section{Androgen-activated AR represses transcription of the GPER1 gene}

Since the GPER1 promoter has not been fully characterized yet, Rapid Amplification of cDNA Ends (RACE) experiment was performed on LNCaP cells to determine the transcription start sites (TSSs) (Supplementary Figure 1). We found 1 TSS corresponding with GPER1 mRNA variants 2 and 3 (which share the same promoter) and 2 TSSs corresponding with variant 4 . Variant specific primers (Supplementary Table 1) were only able to amplify variants 2 (GPER1v2) and 4 (GPER1v4), and both variants are encoded for the same protein. PCR reactions against all other GPER1 variants found no detectable expression (data not shown). To determine whether GPER1v2 or GPER1v4 were selectively repressed by DHT, two variant specific primers overlapping intronic regions were compared to a primer pair internal to the GPER1 exon which would effectively amplify all GPER1 variants (Figure 1A). When treated with DHT, both GPER1v2 and GPER1v4 were repressed to a similar degree (58\% reduction and 69\% reduction respectively) within 48 hours in $\mathrm{LNCaP}$ cells (Figure 1B). Since the degree of repression was similar, the primer pair spanning only the $5^{\prime}$ exon of GPER 1 was used to examine total GPER1 mRNA abundance for future experiments when possible. Taken together, these observations indicated that GPER1v2 and GPER1v4 were the sole GPER1 transcripts expressed in LNCaP cells, and these transcripts were repressed by DHT treatment to a similar degree.

LNCaP, C4-2, and $\mathrm{VCaP}$, all $\mathrm{AR}+$ cell lines, were treated with $10 \mathrm{nM}$ DHT for 24-48 hours to compare relative expression of all GPER1 transcripts. Androgenmediated AR activity significantly repressed GPER1 mRNA levels in LNCaP (57\%), C4-2 (46\%), and VCaP cells $(85 \%)$ after $24 \mathrm{hrs}$ and even further by $78 \%$, $63 \%$ and $95 \%$ respectively after $48 \mathrm{hrs}$ (Figure 1C). Furthermore, in LNCaP cells, the repression of GPER1 was alleviated by co-treatment with $10 \mu \mathrm{M}$ bicalutamide, an AR antagonist (Figure 1D). As R1881 was a common agonist for AR in certain assays due to its stability, we compared it to DHT with respect to GPER1 expression. Both physiological $(10 \mathrm{nM})$ and pharmacological (100 nM) concentrations of DHT and matching concentrations of R1881 repressed GPER1 to the same degree (Supplementary Figure 2).

Nuclear run-on assays confirmed that $10 \mathrm{nM}$ DHT inhibited the rate of GPER1v2 and GPER1v4 transcription (Figure 2A). In this assay, the PSA gene, a known ARupregulated gene, was included and served as gene 
control. In contrast to that observed for GPER1, addition of DHT strongly increased PSA transcription by nearly 60 fold (Supplementary Figure 3). Pulse-chase experiments with actinomycin D on cells pretreated with DHT for 12 hours showed that GPER1 transcripts are rapidly degraded within 6 hours; however, this rate of degradation was similar between vehicle and DHT treated groups (Figure 2B). This contrasts with the PSA transcript which is highly stable after androgen treatment and was induced by the $12 \mathrm{hr}$ DHT pre-treatment (Figure 2B). Together, these observations indicate that both GPER1v2 and GPER1v4 are repressed by the androgen activated AR, and the decrease in GPER1 mRNA transcripts following DHT treatment is due to a decreased transcription and not due to decreased mRNA stability.

\section{Sp1 and Sp3 co-regulate the basal expression of GPER1 and are implicated in AR mediated repression of GPER1}

Our previous data [17] along with other public datasets (NCBI GEO data sets: GSE39879, GSE62472,

A

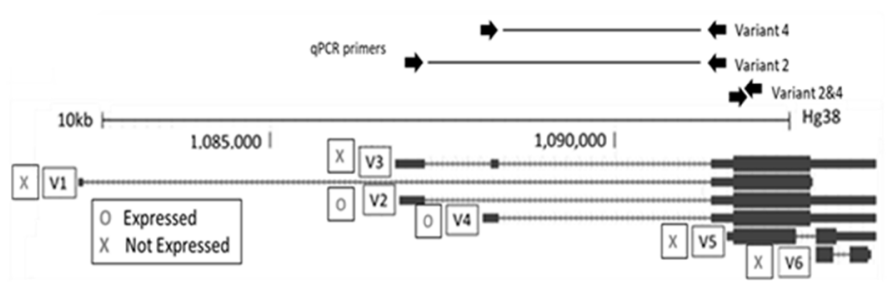

C

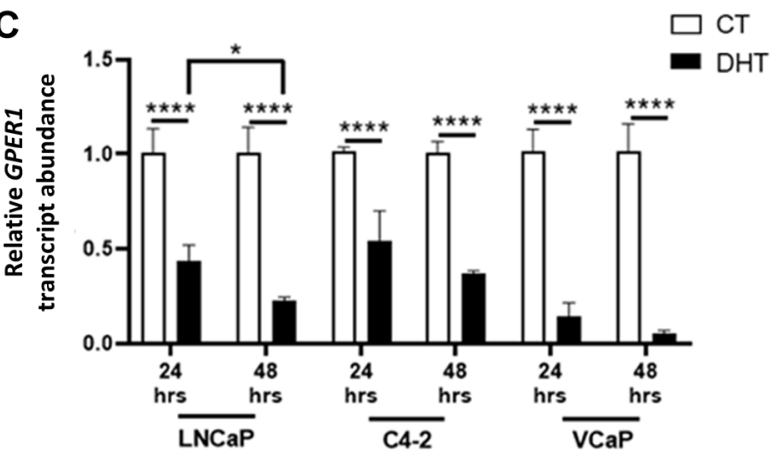

GSE43791, GSE27823, GSE69043 and GSE84432) showed no AR binding activity in the $5^{\prime}$ proximal promoter of GPER1, and the ChIP-seq data showed that the closest binding signal is about $3 \mathrm{~kb}$ downstream of GPER1's last exon. Since it has been reported that the AR can regulate gene expression without direct DNA binding, we investigated if androgens could modulate GPER1 promoter activity in a luciferase-based promoter assay. Four fragments (A: v2\&v4 2604bps, B: v2 1135 bps, C: v4 1178 bps, and D: v4 635 bps) spanning the GPER1 TSS's (Supplementary Figure 4) at the promoter region were cloned using a pGL3 basic vector (Figure 3A). Interestingly, androgen treatment repressed promoter activity of each GPER1 promoter tested (Figure 3A). The $635 \mathrm{bp}$ fragment of GPER1 variant 4's promoter (promoter fragment D) had the strongest activity and contained three predicted Sp1/Sp3 binding sites (Figure 3A). Site-directed mutagenesis on the Sp1/ Sp3 predicted binding sites of promoter fragment D was performed as indicated in Figure 3B. Mutation of all three $\mathrm{Sp} 1 / \mathrm{Sp} 3$ sequences significantly reduced basal activity of the GPER1 promoter whereas no significant difference

\section{B}

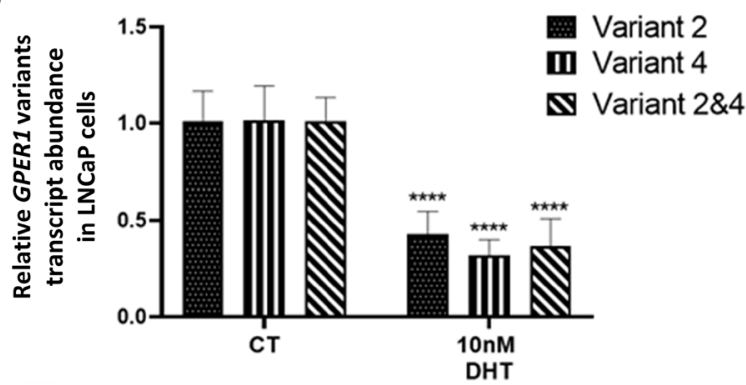

D

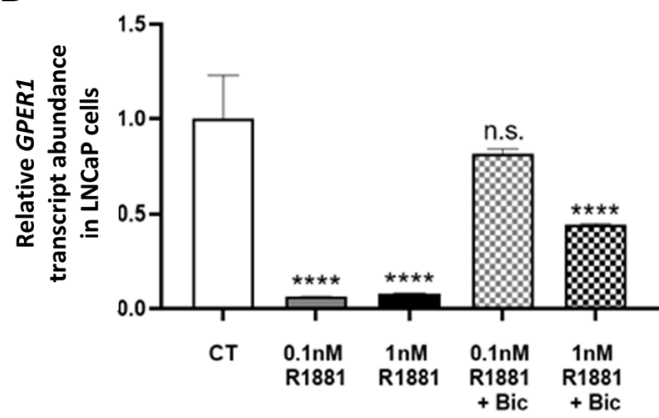

Figure 1: Androgen treatment represses GPER1 mRNA in AR positive PCa cell lines. (A) Screenshot of GPER1 mRNA variants from UCSC Genome Browser. [O] indicates the transcript variant is expressed, and $[\mathrm{X}]$ indicates no expression in LNCaP cells. (B) LNCaP cells were treated with vehicle or $100 \mathrm{nM} \mathrm{DHT}$ for $48 \mathrm{hrs}$. Expression of GPER1 mRNA variants 2 and 4 were measured both separately (primers spanning variant-specific splice junctions) and together (primers within GPER1 exon common to both variants) by RTqPCR. Primer sites are shown in (A) and primer sequences are in Supplemental Table 1. $n=6$. Error bars are plotted as standard deviation, and 2-way ANOVA was performed to compare gene expression between $\mathrm{CT}$ and DHT treated groups for respective $\mathrm{mRNA}$ variants $\left({ }^{* * * *}=p\right.$ $<0.0001$ ). (C) C4-2, LNCaP, and VCaP cells were treated with vehicle (CT) or $10 \mathrm{nM}$ DHT for 24 and 48 hrs. Total GPER1 expression was analyzed by RT-qPCR. For C4-2 24 hrs treated: $n=4$. For all remaining groups: $n=6$. Error bars are plotted as standard deviation. 2 -way ANOVA was performed to compare gene expression between CT and DHT groups for a particular cell line and treatment time $\left({ }^{* * * *}=p<\right.$ $0.0001)$ and to compare LNCaP $24 \mathrm{hrs}$ DHT treated with $48 \mathrm{hrs}$ DHT treated $\left({ }^{*}=p<0.05\right)$. (D) Total GPER1 expression was measured in LNCaP cells treated with indicated combinations of vehicle (CT), $0.1 \mathrm{nM}$ or $1 \mathrm{nM}$ R1881 and $10 \mu \mathrm{M}$ bicalutamide for 96 hrs by RT-qPCR. $n=4$. Error bars are plotted as standard deviation. 1-way ANOVA was applied to compare gene expression between the various R1881 and bicalutamide treatment groups with the CT group (n.s. = not significant; ${ }^{* * * *}=p<0.0001$ ). 
was observed in all DHT-treated groups (Figure 3C). In summary, the basal activity of the GPER1 promoter is dependent on the $\mathrm{Sp} 1 / \mathrm{Sp} 3$ consensus sequences. Mutation of these sites reduces basal promoter activity similar to androgen treatment.

To determine if androgen treatment modulates the expression of $\mathrm{Sp} 1$ or $\mathrm{Sp} 3$, western blot analysis was performed on $\mathrm{LNCaP}, \mathrm{C} 4-2$, and $\mathrm{VCaP}$ cells treated with DHT. We found that $\mathrm{VCaP}$ cells (which repress GPER 1 mRNA expression to the highest degree of the tested cell types (Figure 1C)) show a 75\% reduction in $\mathrm{Sp} 1$ protein expression after DHT treatment (Figure 4). $\mathrm{VCaP}$ cells showed two bands for $\mathrm{Sp} 3$ protein which were both repressed by DHT treatment (43\% reduction for the lower MW band and 55\% reduction for the higher MW band). The higher MW Sp3 band seen only in the VCaP cells is potentially modified by SUMOylation which has been previously reported [46]. C4-2 cells showed a 67\% reduction in $\mathrm{Sp} 3$ protein expression, but $\mathrm{Sp} 1$ remained relatively unaffected, and LNCaP cells showed similar expression levels for both $\mathrm{Sp} 1$ and $\mathrm{Sp} 3$ with or without DHT treatment (Figure 4). To manipulate the expression of Sp1 and Sp3 in cell lines, we chose LNCaP cells for all subsequent analysis because we established a high transfection efficiency protocol for both siRNAs (Figure 5B and 5C) and plasmids (Supplementary Figure 5) with this particular cell line.

Knockdown of $\mathrm{Sp} 1$ and $\mathrm{Sp} 3$ alone or in combination was performed, and the subsequent impact on basal GPER1 mRNA expression and AR- mediated repression was determined by RT-qPCR (Figure 5A). Knocking down either Sp1 or Sp3 expression decreased basal GPER1 mRNA levels modestly (13\% and 28\% reduction respectively); however, in combination, Sp1/ Sp3 knockdown significantly decreased basal GPER1 mRNA levels by $43 \%(p=0.0012)$. Of note, knockdown of $\mathrm{Sp} 3$ alone caused a reciprocal $92 \%$ increase in $\mathrm{Sp} 1$ protein levels (Figure 5B), and knockdown of Sp1 alone increased Sp3 protein levels by 41\% (Figure 5C). These observations indicate a compensatory mechanism by which $\mathrm{Sp} 1$ and $\mathrm{Sp} 3$ regulate both each other and the basal rate of GPER1 gene transcription. Not surprisingly, knockdown of Sp1 and Sp3 levels did not alter the DHT/AR mediated inhibition of GPER1 transcription (Figure 5A). siRNA knockdown of Sp4 was also performed as Sp4 binds the same consensus sequences as $\mathrm{Sp} 1 / \mathrm{Sp} 3$, and Sp4 protein expression has been shown in LNCaP cells $[44,45]$. While DHT treatment and siRNA knockdown both significantly repressed Sp4 transcript expression (47\% and 57\% respectively) (Supplementary Figure 6A), knockdown of Sp4 did not impact basal GPER1 mRNA expression or DHT mediated repression (Supplementary Figure 6B).

In parallel, overexpression experiments were performed to determine if increasing $\mathrm{Sp} 1$ and/or Sp3 levels would impact basal expression or AR-mediated repression of GPER1. LNCaP cells were transfected with vectors containing the CMV promoter to overexpress $\mathrm{Sp} 1$ (pN3-Sp1) and/or Sp3 (pN3-Sp3). Overexpression of CMV-Sp1 or CMV-Sp3 led to a slight rise in basal GPER1 mRNA levels (12\% and $13 \%$ respectively), although this was not statistically significant (Figure 5D). No change was observed in the repression of GPER1 mRNA by DHT treatment when comparing the empty vector control (68\% reduction) with either only CMV-Sp1 (68\% reduction) or CMV-Sp3 (69\% reduction) (Figure 5D). In contrast, CMV-Sp1/CMV-Sp3 co-overexpression alleviated the inhibitory effects of androgen-activated AR and significantly restored GPER 1 transcription (22\% reduction compared to the empty vector vehicle control). Over-expression of Sp1 and Sp3 was confirmed by western blot (Figure 5E and 5F).
A

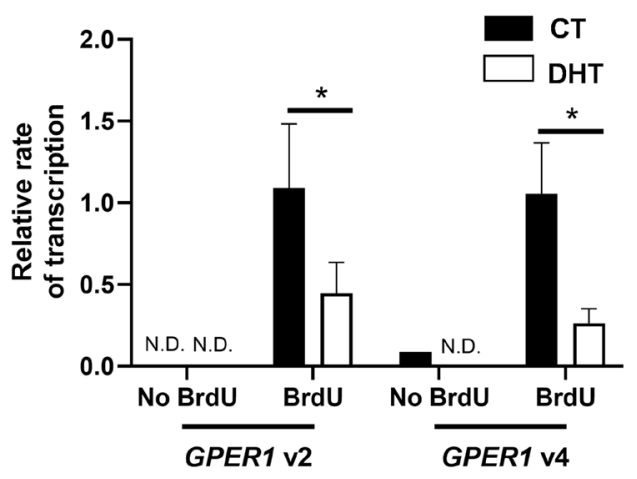

B

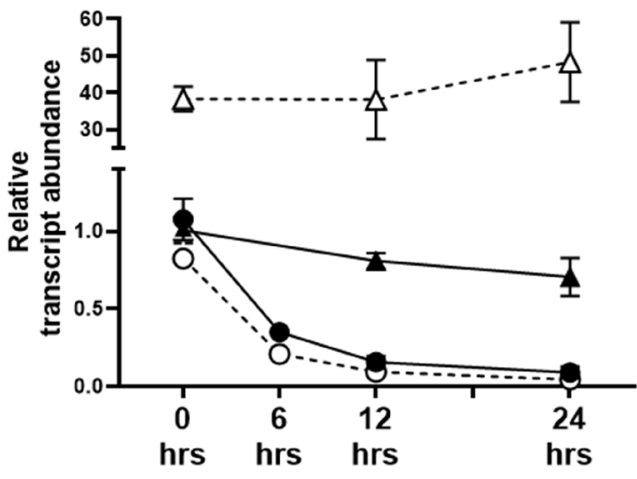

Figure 2: The AR represses transcription of GPER1 but not mRNA stability. (A) Nuclear Run-on RT-qPCR was performed on LNCaP cells treated with vehicle (CT) or DHT for $48 \mathrm{hrs}$ and relative transcription of GPER1 mRNA variant 2 and variant 4 was assessed by RT-qPCR. No BrdU CT: $n=1$, No BrdU DHT: $n=2$, BrdU CT: $n=3$, and BrdU DHT: $n=4$. Error bars are plotted as standard deviation. 2-way ANOVA was performed to compare relative rate of transcriptions between CT and DHT treated groups for respective mRNA variants $\left({ }^{*}=p<0.05\right)$. N.D. $=$ not detected. (B) LNCaP cells were pretreated with the vehicle (DMSO, CT) or $100 \mathrm{nM} \mathrm{R} 1881$ for $12 \mathrm{hrs}$ before 10 $\mu \mathrm{M}$ of actinomycin D was added at indicated time 0 . RNA was collected at $0,6,12$, and $24 \mathrm{hrs}$ after addition of actinomycin D, and mRNA abundance of GPER1 was assessed by RT-qPCR. $n=4$. 


\section{DHT treatment reduces time-dependent binding of Sp1, Sp3, and RNA pol II at the promoter of GPER1 upon serum stimulation and induces nuclear interactions between AR with Sp1 and Sp3}

Seven putative Sp1/Sp3 binding sites were identified in the GPER1 proximal promoter regions (Figure 6A). To see if the DHT treatment modulated binding of Sp1 or Sp3 to the promoter of GPER1 to impact transcription, we performed ChIP-qPCR on Sp1, Sp3, and RNA pol II at these seven sites. As previous RT-qPCR data showed that GPER 1 expression positively correlated with serum concentration (Supplementary Figure 7), we decided to incubate LNCaP cells in low serum media ( $1 \%$ CSS) for 48 hrs before both switching to high serum media (10\% CSS) and beginning DHT treatment. We found that switching to high serum media led to an increase in Sp3 binding at the promoter of GPER 1 after $2 \mathrm{hrs}$ which was reduced at 5 hrs (Figure 6D). In contrast, Sp1 (Figure 6F) and RNA pol II (Figure 6B) binding was observed at $5 \mathrm{hrs}$ post serum stimulation. DHT treatment significantly prevented Sp1

A

WT Sp1 binding site

GPER1 A

GPER1 B

GPER1 C

GPER1 D

pGL3 basic

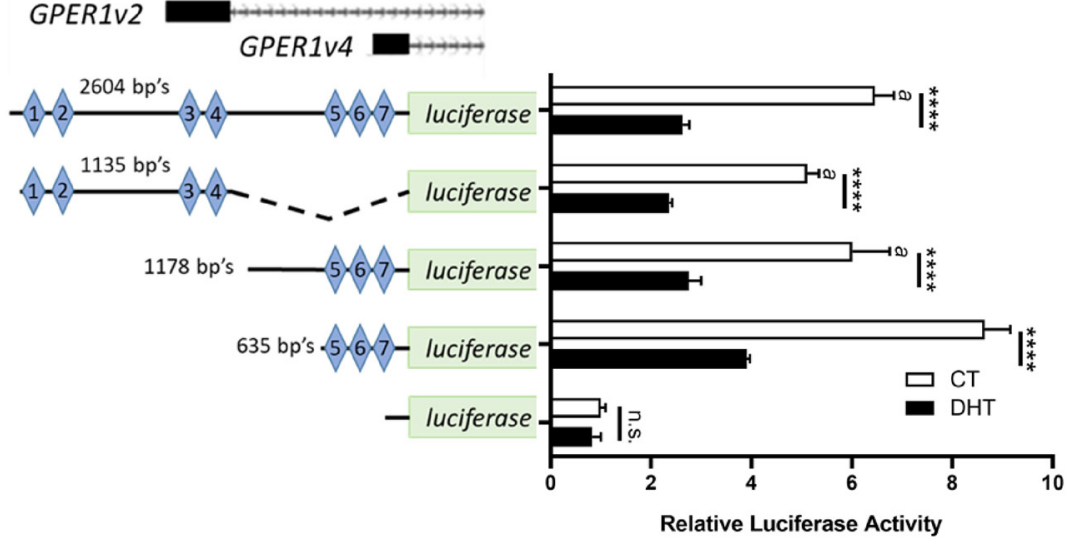

B

>Promoter Fragment D (635 bps) site-directed mutagenesis

-3774 TGGATCATGCACATGCTACTAAGTTAATTATGAAATTTAGTGTTTAACGC

-3724 AGGTCAGTTGCAAAAACAAGAATATTGCTTGCTTCAACCCAGGAGGACAG

-3674 GTTATTGCCTAAAAGATACACAACACCTAGTATGATGCCTTCAAACTTAA.

-3624 AGAAAGGTTTGTATCTGTGGGTGAAGAAAAGCAGTTAAACCAGAAACTTC

-3574 CACAAAAACAAGTCTAGTAGAACTGAGCTGATTGCCAAAGTGTGGGAGAA

-3524 AAAGGGCCAGCAAAAAAATGGTTAACACTAGCCTTCTGAGGAGGCCGCCC

-3474 AGAGCCTGGCCAGAGAGGAGCCA GA $\underset{\Gamma-3395}{\frac{139 G G G G G C G G A G G G G C C T A T}{\text { Site } 6}}$

$\mathbf{0 3 2 4}$ AAAGCCCTGTGCCAAGGGGCAGACTCACTGGCTCAGAGGGAGGACGCACC

-3374 CGCCAGCCAGCCGGGAACCTTCCCTCGCGGGCTCCCA $\frac{\text { GGGCGGGTCTCTT }}{\text { Site }}$

-3324 CCTCTCTCTAGCCCTGCTCAGGCATTCGGCAGGTCCAGCAGAGGTACACC

-3274 TCCTGCAGCGGGTTCCAAGTGCACCTCCAGCCTGATGGGCCTGACCAAGG

-3224 AGGCTTCCAGGAGCACAGAAGGGGCTGCAACCCAGGTAGGACTCAGCCTC

$\mathbf{- 3 1 7 4}$ GGCCTGGCGGTGCCATACCACTGACTAGGGGAGCG
C

WT Sp1 binding site

Mutated Sp1 binding site

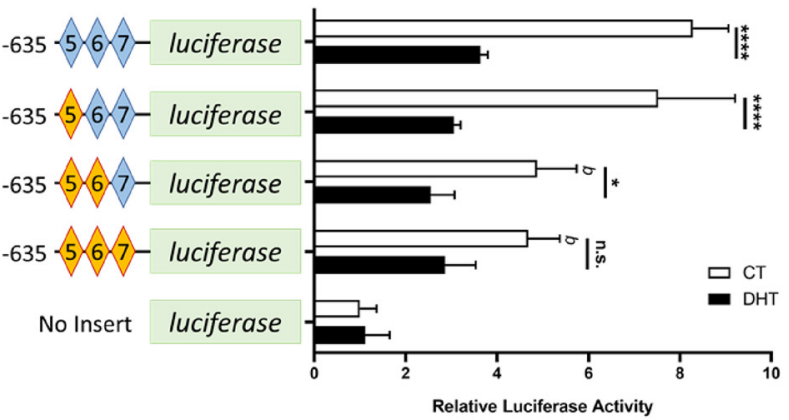

Figure 3: GPER1v2 and GPER1v4 promoters are repressed by androgens and deletion of predicated Sp1/Sp3 consensus sequences reduces basal expression in the GPER1v4 promoter. (A) LNCaP cells were transfected with the empty pGL3 basic vector or pGL3 basic vectors with cloned inserts of the GPER1 promoters. The y-axis diagrams the GPER1 promoter fragments cloned into pGL3 reporter plasmid with predicted Sp1/Sp3 binding sites indicated by blue diamonds. $6 \mathrm{hrs}$ after transfection, cells were switched to hormone deprived media and treated with vehicle (CT) or $10 \mathrm{nM}$ DHT. After $48 \mathrm{hrs}$ of DHT treatment, luciferase assay was performed, normalized to beta-galactosidase, and standardized to the empty pGL3 basic CT group. $n=3$. Error bars are plotted as standard deviation, and 2-way ANOVA was performed. [ $a$ ] indicates significant differences $(p<0.0001)$ in luciferase activity when compared to promoter D CT group, and significant differences in luciferase activity between vehicle (CT) and DHT treated groups for each promoter is indicated by bars $\left(^{* * * *}=p<0.0001\right)$. (B) The WT sequence information for promoter fragment D is presented including mutations present at $\mathrm{Sp} 1 / \mathrm{Sp} 3 \mathrm{consensus}$ sequences as highlighted in red. (C) Luciferase reporter assay was performed and analyzed as in (A) on the WT GPER1 promoter fragment $\mathrm{D}$ and mutant plasmids. $n=3$. Error bars are plotted as standard deviation, and 2-way ANOVA was performed. [b] indicates significant differences $(p<0.005)$ in luciferase activity when compared to the WT promoter D CT group, and significant differences in luciferase activity between vehicle (CT) and DHT treated groups for each respective promoter is indicated by black bars $\left(\mathrm{n} . \mathrm{s} .=\right.$ not significant; ${ }^{*}=p<$ $\left.0.05 ;{ }^{* * *}=p<0.0001\right)$. 
and RNA pol II binding seen at all 7 sites and significantly prevented Sp3 binding only at site 3. Interestingly, sites 5, 6 , and 7 showed relatively weak Sp1, Sp3, and RNA pol II binding compared to the other upstream binding sites despite their relevance in promoter activity in the initial reporter assay used to implicate the relevance of these TFs (Figure 3C). The GAPDH primer pair used to normalize RT-qPCR results was used as a negative control site as there were no nearby Sp1/Sp3 consensus sequences, and antibody specificity for the ChIP-qPCR was verified by siRNA knockdown samples for Sp3 (Figure 6C) and Sp1 (Figure 6E). Taken together, it appears that $\mathrm{Sp} 3$ primes the GPER1 promoter for transcription through unknown mechanisms, followed by Sp1 and RNA Pol II binding to initiate transcription of GPER1, and AR activation inhibits DNA binding of all three of these proteins to repress GPER1 transcription.

As there is no evidence of direct or indirect AR binding to the promoter of GPER1, we sought to determine whether the AR-mediated repression of GPER 1 transcription occurred through AR interactions with Sp1 or $\mathrm{Sp} 3$ to reduce nuclear localization and/or decrease DNA binding potential. Nuclear and cytoplasmic coImmunoprecipitation (CoIP) experiments were performed in LNCaP cells using the same treatment conditions as for the ChIP assay. Sp1 (Figure 7B) and Sp3 (Figure 7C) were primarily localized to the nucleus and neither their levels nor nuclear localization were altered by DHT treatment. Immunoprecipitation (IP) of the AR was shown to be specific compared to the IgG control (Figure 7A). Importantly, only nuclear AR co-immunoprecipitated with both Sp1 (Figure 7B) and Sp3 (Figure 7C) and DHT was required for this interaction to occur. Together these results imply that DHT-activated AR binds both Sp1 and Sp3 in the nucleus to sequester them and prevent their binding to $\mathrm{Sp} 1 / \mathrm{Sp} 3$ binding sites in the GPER1 promoter region.

\section{DISCUSSION}

Here we report for the first time an instance of AR gene repression being mediated through both Sp1 and Sp3. In this study, the androgen bound AR directly

\begin{tabular}{r|c|c|c|c|c|c|}
\hline Cell Type: & \multicolumn{2}{|c|}{ LNCaP } & \multicolumn{2}{c|}{ C4-2 } & \multicolumn{2}{c|}{ VCaP } \\
\hline Treatment: & CT & DHT & CT & DHT & CT & DHT \\
\hline Expression: & 100 & 89 & 100 & 89 & 100 & 25 \\
Sp1 $100 \mathrm{kDa} \rightarrow$ t
\end{tabular}
N.S. $75 \mathrm{kDa} \rightarrow$ Actin

\begin{tabular}{|c|c|c|c|c|c|c|}
\hline Expression Top Band: & & & & & 100 & 45 \\
\hline Expression Bottom Band: & 100 & 94 & 100 & 33 & 100 & 57 \\
\hline Sp3 $_{\substack{150 \mathrm{kDa} \rightarrow \\
100 \mathrm{kDa} \rightarrow}}$ \\
Actin $_{37 \mathrm{kDa} \rightarrow}$
\end{tabular}

Figure 4: Differential protein expression of $\mathrm{Sp1}$ and $\mathrm{Sp3}$ after androgen treatment in different prostate cancer cell lines. Western blot on LNCaP, C4-2, and VCaP cells after 48 hrs of DHT treatment probing for Sp1, Sp3 and Actin (Cropped blots). Arrows indicate marker bands. Band intensity was quantified on Image Studio software Ver 5.2. Expression was calculated by normalizing Sp1 or Sp3 band intensity to actin band intensity and standardizing each lane to the CT lane. 
represses GPER1 transcription, but not mRNAstability, by interacting with two essential transcription factors of GPER1, Sp1 and Sp3. The nuclear interactions between AR with Sp1 and Sp3 prevent them from binding to and activating transcription at the GPER1 promoters. As Sp1 and Sp3 are overexpressed in most cancer types [47], have been characterized as non-oncogene addiction genes [48], and have been studied as potential biomarkers for recurrent $\mathrm{PCa}$ [49], these key findings highlight the importance of examining the $\mathrm{AR}, \mathrm{Sp} 1$ and $\mathrm{Sp} 3$ signaling axis in PCa.
The relationship between $\mathrm{Sp} 1$ and $\mathrm{Sp} 3$ is still in debate. While Sp3 has been shown to repress the transactivation potential of Sp1 depending on gene context [39], Sp3 has also been reported to work with Sp1 for collaborative activation of target genes [41, 50, 51]. In line with the cooperative relationship of $\mathrm{Sp} 1$ and $\mathrm{Sp} 3$ target gene expression, modulation of both $\mathrm{Sp} 1$ and $\mathrm{Sp} 3$ together is required to impact GPER1 expression and AR-mediated repression. Interestingly, our data revealed that $\mathrm{Sp} 1$ and Sp3 appear to co-regulate their protein levels of expression in a compensatory manner. In LNCaP cells, the loss of
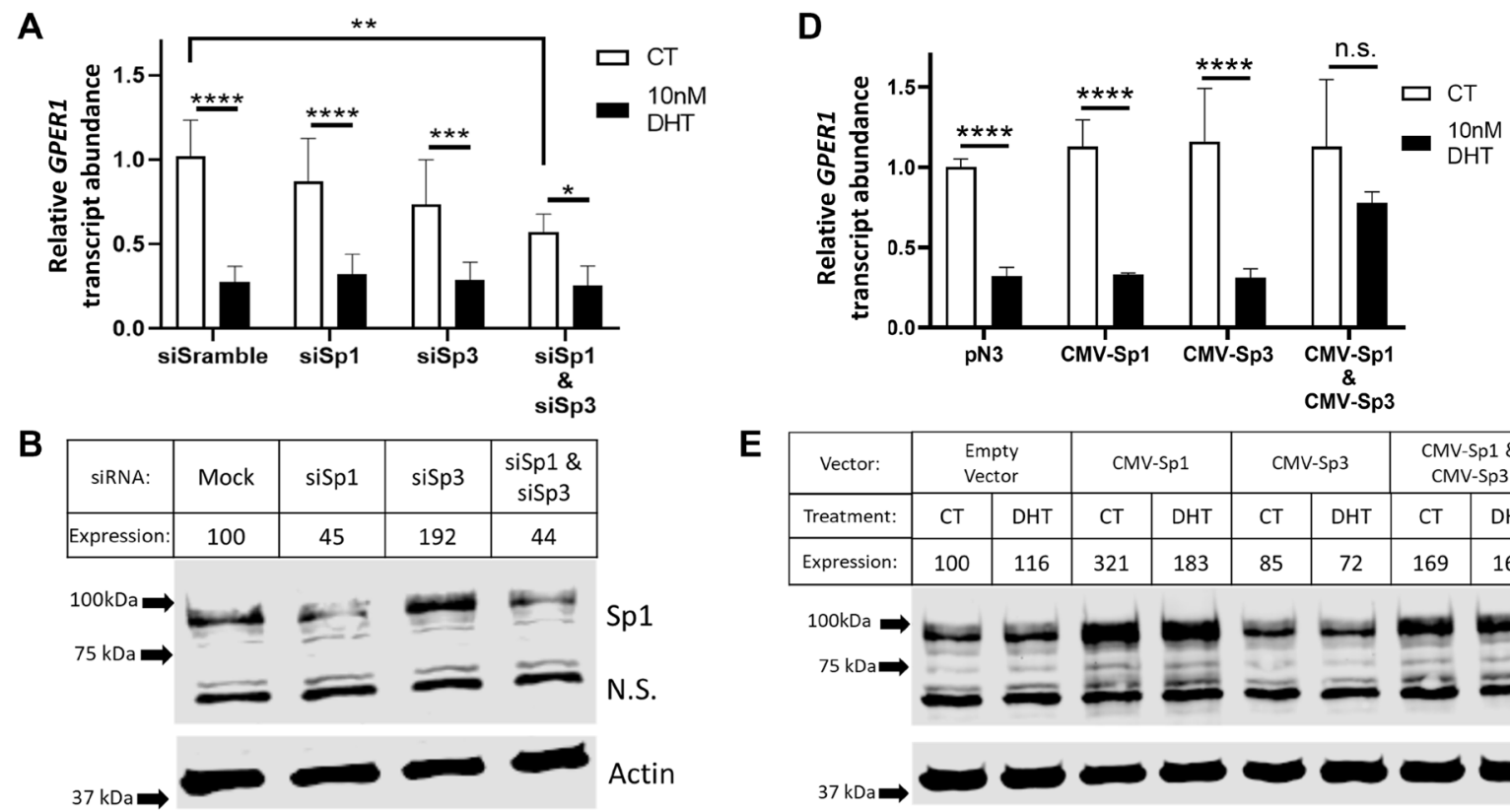

E

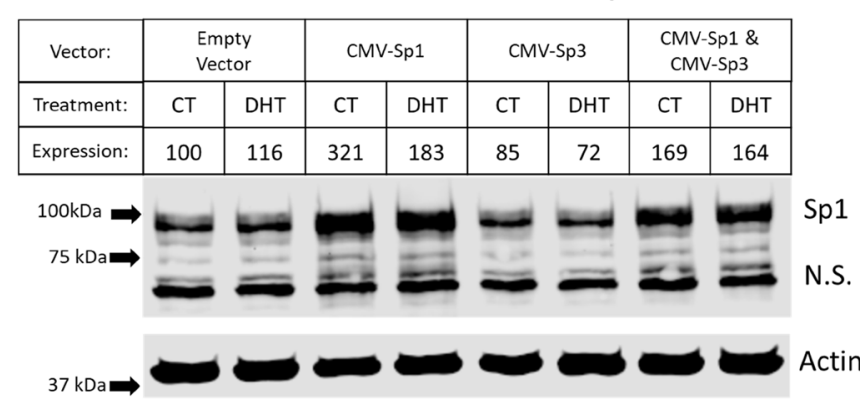

C

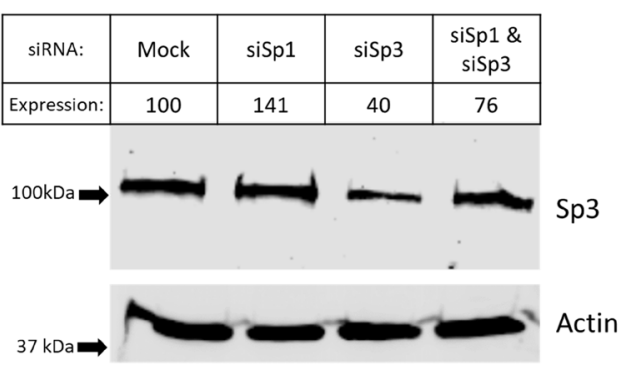

F

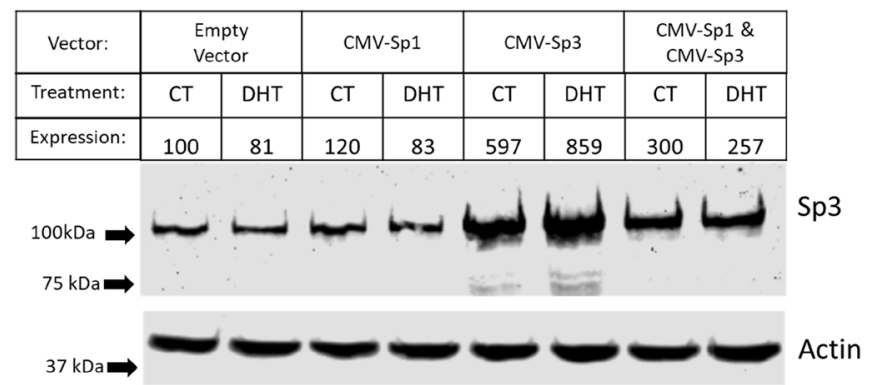

Figure 5: Potentially due to compensatory regulation, both $\mathrm{Sp1}$ and $\mathrm{Sp3}$ are implicated in regulation of GPER1. (A) LNCaP cells were transfected with scramble siRNA or siRNA targeting Sp1 and/or Sp3. 6 hrs later, the cells were rinsed with PBS twice and switched to hormone deprived media. After 42 hrs, cells were treated either with vehicle (CT) or with $10 \mathrm{nM}$ DHT for 48 hrs before RNA was isolated for RT-qPCR on target genes. $n=6$. Error bars are plotted as standard deviation, and 2-way ANOVA was performed to compare changes in gene expression between vehicle (CT) and DHT treated groups within the same and across different transfection groups. Significant changes are indicated $\left({ }^{*}=p<0.05 ;{ }^{* * *}=p<0.01 ;{ }^{* * *}=p<0.001 ;{ }^{* * * *}=p<0.0001\right)$. (B) LNCaP cells were transfected as in (A). 6 hrs later, cells were rinsed with PBS twice and switched to hormone deprived media was added. After 42 hrs, protein was isolated for western blot analysis probing against Sp1 and actin. Arrows indicate marker bands. Band intensity was quantified on Image Studio software Ver 5.2. Expression was calculated by normalizing Sp1 band intensity to actin band intensity and standardizing each lane to the CT lane (Cropped blots). (C) Western blot as in (B) against Sp3 and actin. Arrows indicate marker bands. Band intensity was quantified on Image Studio software Ver 5.2. Expression was calculated by normalizing Sp1 band intensity to actin band intensity and standardizing each lane to the CT lane. (Cropped blots). (D) LNCaP cells were transfected an empty plasmid (pN3) or CMV-Sp1 and/or CMV-Sp3 and followed the same treatment and analysis as in (A). $n=6$. Error bars are plotted as standard deviation, and 2-way ANOVA was performed to compare changes in gene expression between vehicle (CT) and DHT treated groups within the same and across different transfection groups. Significant changes are indicated (n.s. $=$ not significant; ${ }^{* * * *}=p<0.0001$ ). (E) Western blot probing against Sp1 and actin for samples in (D) (Cropped blots). (F) Western blot probing against Sp3 and actin for samples in (D) (Cropped blots). 
Sp3 expression after siRNA knockdown is compensated by increased expression of $\mathrm{Sp} 1$ protein as observed in our western blot data. This phenomenon may mask the actual effect of Sp3 knockdown on GPER1 expression. Therefore, the degree of Sp3 involvement in supporting the basal expression of GPER 1 could be under-estimated.
Several studies have suggested that Sp3 is involved in promoting transcription in response hormones and growth factors; whereas a primary functional role of $\mathrm{Sp} 1$ is to drive basal transcription [52-55]. Our results support this mechanism by showing that upon serum stimulation, Sp3 binding precedes Sp1, and when Sp1 was bound,
A

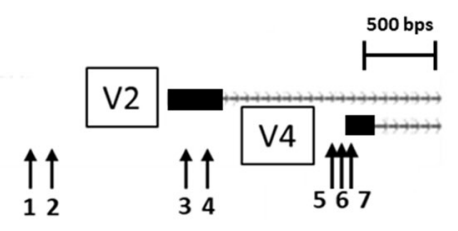

Potential Sp1/Sp3 binding sites
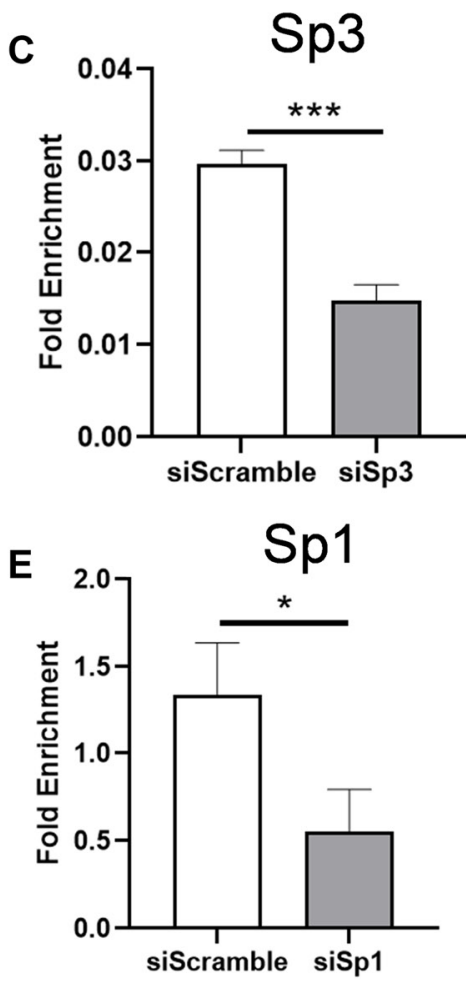

B

D
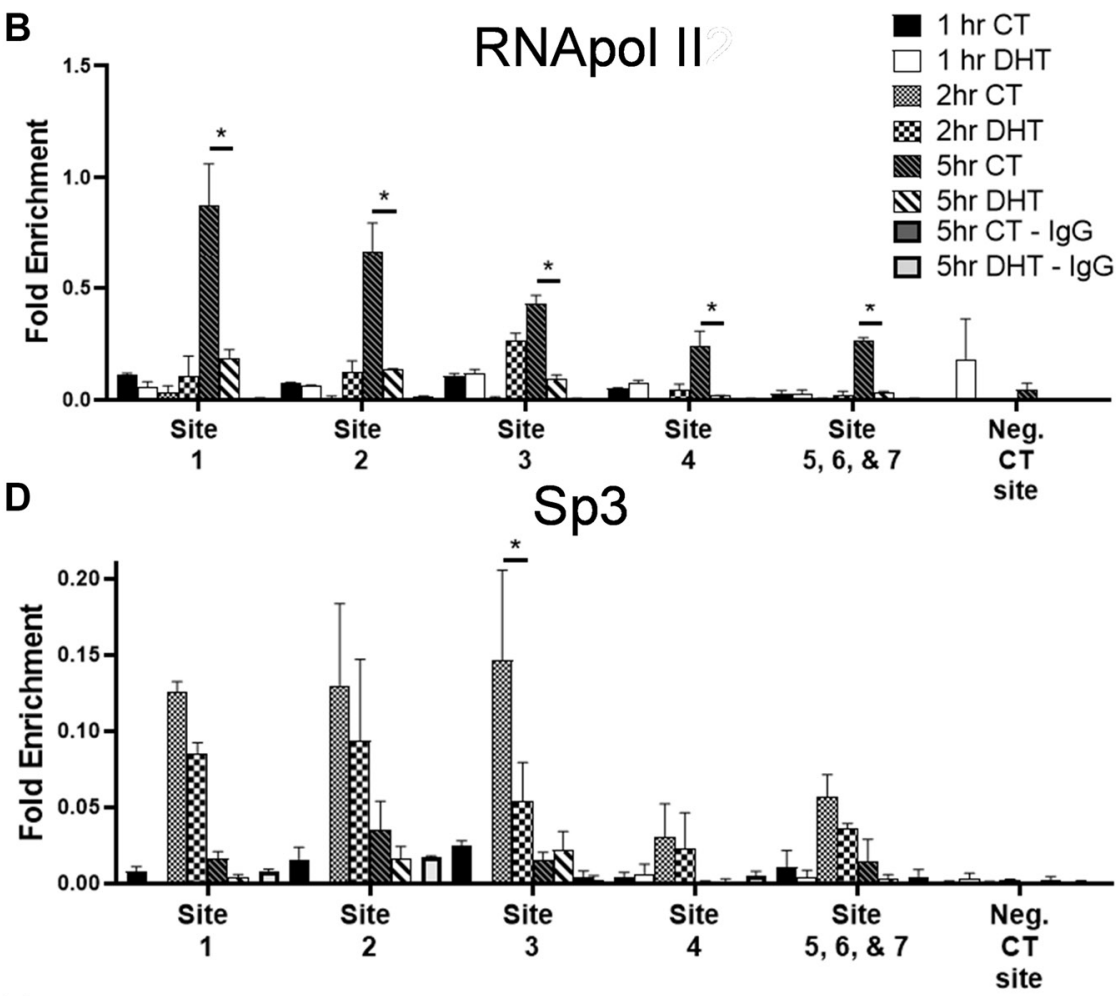

$\mathbf{F}$

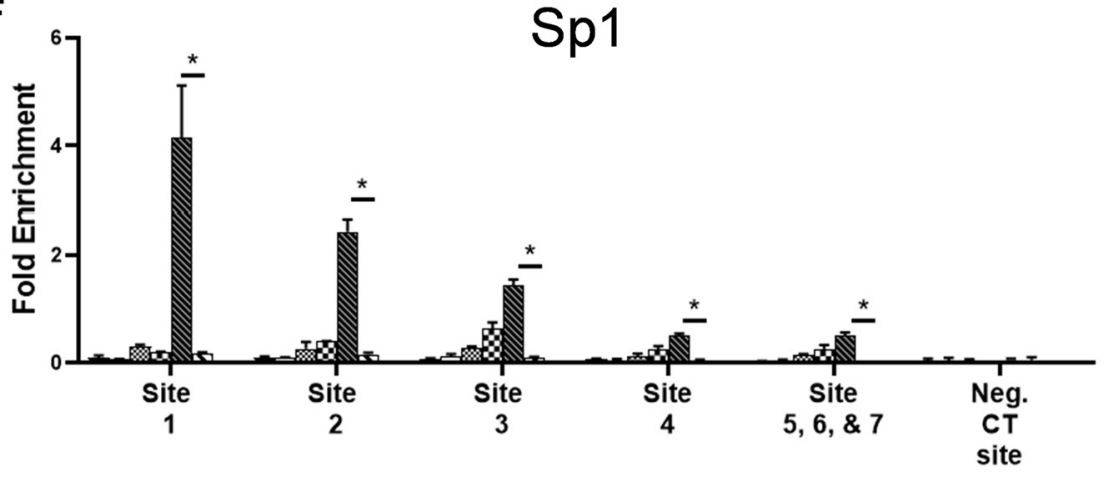

Figure 6: DHT treatment reduces Sp1, Sp3 and RNA pol II binding at the promoter of GPER1 following addition of complete media after low serum. (A) Sp1 consensus binding sequencing around the GPER1 gene are depicted. (B) LNCaP cells were switched to low serum media (1\% CSS). After $48 \mathrm{hrs}$, cells were treated with vehicle (CT) or $10 \mathrm{nM}$ DHT in high serum media (10\% CSS) for indicated timepoints. ChIP-qPCR for RNA pol II at predicted Sp1/Sp3 binding sites indicated in (A) was performed. The negative CT site was the GAPDH qPCR primer pair as it had no predicted Sp1/Sp3 binding sites within $1.5 \mathrm{~kb}$ of the amplicon in either direction. deltaCT values were normalized to the input group. $n=2$. (C) LNCaP cells transfected with siRNA targeting Sp3 were switched to low serum media (1\% CSS) $6 \mathrm{hrs}$ post transfection for $48 \mathrm{hrs}$ before switching to high serum media (10\% CSS) and treating with vehicle (CT) or $10 \mathrm{nM}$ DHT for $2 \mathrm{hrs}$. ChIP-qPCR for Sp3 was performed at site 2. $n=3$. Error bars are plotted as standard deviation, and Student's $t$ test was performed ${ }^{* * *}=p<0.001$ ). (D) ChIP-qPCR for Sp3 was performed as detailed in (B). $n=2$. Error bars are plotted as standard deviation, and 2-way ANOVA was applied to compare fold enrichment between vehicle (CT) and DHT treated groups within the same treatment time and at the same predicted Sp1/Sp3 sites $\left({ }^{*}=p<0.05\right)$. (E) LNCaP cells transfected with siRNA targeting Sp1 were treated as in (C) for $5 \mathrm{hrs}$. ChIP-qPCR for Sp1 was performed at site 2. $n=3$. Error bars are plotted as standard deviation, and Student's $t$ test was performed $\left({ }^{*}=p<0.05\right)$. (F) ChIP-qPCR for Sp1 was performed as detailed in (B). $n=2$. Error bars are plotted as standard deviation, and 2-way ANOVA was applied to compare fold enrichment between vehicle (CT) and DHT treated groups within the same treatment time and at the same predicted $\mathrm{Sp} 1 / \mathrm{Sp} 3$ sites $\left({ }^{*}=p<0.05\right)$. 
RNA polymerase II was also bound (Figure 6B, 6D, 6F). While ChIP and ChIP-seq have shown Sp1 and Sp3 binding sites can largely overlap [56-58], differential nuclear organization of $\mathrm{Sp} 1$ and $\mathrm{Sp} 3$ has been reported by immunofluorescence microscopy [59]. In our experiments, Sp1 and Sp3 both bound the same sites at the GPER1 promoters, but at different times after the addition of higher serum media. Perhaps the discrepancy between which genes are regulated by $\mathrm{Sp} 1$ and which by Sp3 is caused by differences in cell cycle progression between experiments. Indeed it has been shown that the degree of overlap between Sp1 and Sp3 localization changes throughout cell cycle progression, and Sp3 enters in newly formed nuclei before Sp1 thereby having the first opportunity to bind $\mathrm{Sp}$ sites [60]. It is worth speculating that Sp3 could be acting as a pioneer factor for a robust $\mathrm{Sp} 1$ response.

AR mediated gene repression without DNA binding has previously been demonstrated to be mediated through Sp1 [27-29]. To our knowledge, this is the first report implicating Sp3 in AR mediated repression and that the AR interacts with Sp3 (Figure 7C). When considering the mechanism by which the AR modulates Sp1 and Sp3 activity, it is important to determine if the expression is impacted. DU145 cells stably transfected to express the AR have been shown to repress both $\mathrm{Sp} 1$ and $\mathrm{Sp} 3$ in the presence of DHT, while AR+ NRP-154 cells only repressed Sp1 expression [28]. Changes in Sp1 and Sp3 expression in response to DHT treatment in $\mathrm{VCaP}, \mathrm{LNCaP}$, or C4-2 cells has not been previously investigated [8, 26-31, 61, 62]. In our experiments, VCaP cells repressed both $\mathrm{Sp} 1$ and Sp3 protein expression under DHT treatment (Figure 4). This supports Sp1 and Sp3 being involved in GPER1 expression as VCaP cells also showed the greatest degree of GPER1 repression by DHT treatment out of the tested cell types (95\% reduction at $48 \mathrm{hrs}$ DHT) (Figure 1C). C4-2 cells repressed only $\mathrm{Sp} 3$ and $\mathrm{LNCaP}$ cells showed no change in $\mathrm{Sp} 1$ or $\mathrm{Sp} 3$ expression (Figure 4) or localization (Figure 7B and 7C) under DHT treatment. Collectively, these data suggest that the transcriptional suppression of GPER1 by androgen treatment may occur partly through down-regulation of $\mathrm{Sp} 1 / \mathrm{Sp} 3$ (as in the case of VCaP cells) and partly through decreased Sp1 and Sp3 binding to the GPER1 promoters through interactions with the AR.

Expanding our understanding of AR mediated gene repression will be paramount to developing future therapies against PCa. Newer generation ADT drugs such as enzalutamide and abiraterone have led to increased reports highlighting the essential roles of AR repressed genes in the development of treatment resistance. It appears that these drugs at least partly contribute to the development of hormone independent $\mathrm{PCa}$ by abolishing the AR mediated repression of oncogenes. For example, TGF- $\beta$, Cyclin B1, and Cyclin D1 are all repressed by the AR $[8,9,28]$. Cyclin D1 and TGF- $\beta$ pathways are upregulated following ADT [63], and overexpressing CDK4/6 (the downstream target of Cyclin D1) is sufficient to promote enzalutamide resistance [64]. However, the role of AR mediated gene repression in $\mathrm{PCa}$ progression and treatment is complex as the AR has been shown to also directly repress tumor suppressor genes such as DEPTOR [65], E-cadherin [7], c-Met [27], and GPER1 [17]. c-Met is upregulated following $\mathrm{ADT}$ and is to be a promising drug target in advanced CRPC $[66,67]$. Targeting GPER1 with G-1 is a novel approach to treating PCa and was shown previously by us to be an effective treatment in xenograft models of CRPC $[17,68]$.

As therapies that target the AR signaling axis remain central to PCa treatment, more details will emerge regarding the mechanisms of AR-mediated gene repression and their contribution to patient outcomes. With both oncogenes and tumor suppressors being repressed by the androgen
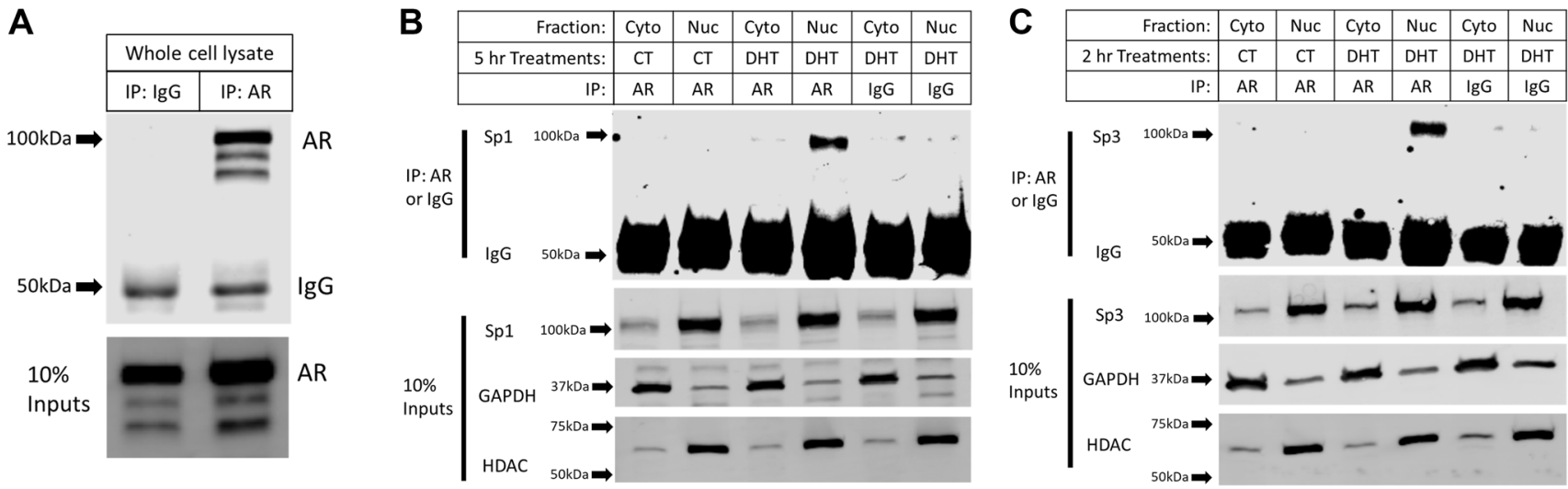

Figure 7: DHT treatment induces nuclear interactions between the AR with Sp1 and Sp3. (A) Co-IP was performed on whole cell lysate from LNCaP cells. IP: AR (ab74272), IB: AR (sc-7305) (Cropped blots). Arrows indicate marker bands. (B) Co-IP was performed on nuclear (Nuc) and cytoplasmic (Cyto) extracts of LNCaP cells treated with 10 nM DHT for 5 hrs. IP: AR (ab74272), IB: Sp1 (ab13370) (Cropped blots). 10\% Input samples were probed for Sp1, HDAC, and GAPDH (Cropped blots). Arrows indicate marker bands. (C) Co-IP was performed on nuclear and cytoplasmic extracts of LNCaP cells treated with $10 \mathrm{nM}$ DHT for 2 hrs. IP: AR (ab74272), IB: Sp3 (ab227856) (Cropped blots). 10\% Input samples were probed for Sp3, HDAC, and GAPDH (Cropped blots). Arrows indicate marker bands. 
activated AR, careful delineation of the impacted target genes will lead to more potent combination therapies that prevent CRPC development. Therefore, we examined ARmediated repression of the newly described targetable tumor suppressor, GPER1. Our novel findings add Sp3 to the list of AR repressed TFs and highlight the importance of examining both $\mathrm{Sp} 1$ and $\mathrm{Sp} 3$ together to fully capture the scope of AR repressed genes. These results provide rationale for targeting GPER1 under ADT and provide the groundwork for discovery of additional AR repressed target gene.

\section{MATERIALS AND METHODS}

\section{Cell lines and cell culture}

Human PC cell lines LNCaP, C4-2, and VCaP were obtained from the American Type Culture Collection (ATCC, Manassas, VA, USA) and recently authenticated [69]. LNCaP cells were maintained in RPMI-1640 medium (Invitrogen) supplemented with 10\% FBS (Gibco) and penicillium/streptomycin. $\mathrm{VCaP}$ cells were maintained in DMEM (Invitrogen) supplemented with 10\% FBS and penicillium/streptomycin. Cells were cultured at $37^{\circ} \mathrm{C}$ and $5 \% \mathrm{CO}_{2}$. For androgen treatment, cells were switched to phenol-red-free media supplemented with $2.5 \%$ charcoalstripped FBS (CSS) (Corning, NY, USA) unless indicated otherwise. DHT and R1881 were dissolved in DMSO as a vehicle and treatment was performed at a 1:10,000 dilution. 24-48 hrs after switching to CSS media, cells were treated with DHT daily or R1881 every other day. Cells were seeded onto poly-1-lysine coated plates for experiments as CSS media reduced cell adhesion.

\section{Knockdown and over-expression of Sp1 and Sp3}

Manufacturer protocols were followed for each transfection reagent used. X-tremeGENE ${ }^{\mathrm{TM}}$ HP DNA Transfection Reagent (Cat\# 6366236001) was used for plasmid transfections and X-tremeGENE 360 Transfection Reagent (Cat\# 8724121001) was used for siRNA transfections. For all transfection assays, cells were transfected and switched to CSS media 6-hrs post transfection. After 48 hrs of incubation, the cells were treated with DHT or vehicle each day for $48 \mathrm{hrs}$. The following siRNAs were used from Invitrogen: Silencer ${ }^{\circledR}$ Select Negative Control No. 1 Cat\# 4390843, Silencer ${ }^{\circledR}$ Select siSp1 Cat\# 4392420 ID: s13318, Silencer $^{\circledR}$ Select siSp3 Cat\# 4392420 ID: s13326, and Silencer ${ }^{\circledR}$ Select siSp4 Cat\# 4392420 ID: s13329. The following plasmids were used from Addgene: pN3 Control Cat\# 24544, pN3Sp1 FL Cat\# 24543, and pN3-Sp3 FL Cat\# 24541.

\section{RNA extraction and RT-qPCR}

All RNA extraction was performed with RNAzol RT (MRC Cat. \# RN 190) following the manufacturer' recommended protocol. Genomic DNA (gDNA)was removed with Promega's RQ1 RNase-Free DNase (Cat. \# M6101) following the manufacturer's protocol. Reverse transcription was performed with Invitrogen's SuperScript III following the manufacturer's protocol with $1 \mu \mathrm{g}$ of RNA input. RT-qPCR was performed on the ViiA 7 Real-Time PCR System in 384 well plates with SYBR SELECT Master Mix (Cat.\#4472919) using primers validated by sequencing amplicons. All primer set reactions contained the following controls for each lot of RT-qPCR reactions:1) RNA input with no reverse transcriptase (gDNA contamination test), 2) no RNA input with reverse transcriptase (RNA contamination of buffers/reagents), and 3) $\mathrm{H}_{2} \mathrm{O}$ RT-qPCR reactions for SYBR Green/primer contaminations. Calculation of relative fold changes was performed as in [68].

\section{Pulse-Chase assay}

After a $48 \mathrm{hr}$ incubation CSS media, cells were treated with $100 \mathrm{nM}$ R1881 or vehicle for $12 \mathrm{hrs}$ before co-treatment with vehicle or R1881 and $10 \mu \mathrm{M}$ actinomycin D. RNA was collected at various time points up to $24 \mathrm{hrs}$. Genes of interest were analyzed by RT-qPCR and normalized to the vehicle treated group before the addition of actinomycin D.

\section{Nuclear run-on assay}

Nuclear run-on RT-qPCR was performed as previously described [70]. Newly synthesized RNAs with $\mathrm{BrU}$ incorporated were enriched by IP with an anti-BrdU $\mathrm{Ab}$ (Sigma Cat\# sc-32323). RT-qPCR was performed with primers (Supplementary Table 1) specially designed for this assay to factor in the lack of splicing in the newly synthesized transcripts.

\section{Protein extraction and western blot}

Cells were rinsed 2 times with cold PBS. Protein was isolated with RIPA buffer (Invitrogen) supplemented with $5 \mu \mathrm{L}$ of Protease Inhibitor Cocktail Set III, EDTA-Free - Calbiochem (Cat. \# 539134) per $1 \mathrm{~mL}$ of RIPA buffer. Protein isolates were incubated on ice for 10 minutes, and then spun at $16,000 \mathrm{~g}$ 's for 10 minutes at $4^{\circ} \mathrm{C}$ to remove cell debris. Protein concentration was calculated by BCA assays, and 20-40 $\mu \mathrm{g}$ of protein lysates were run onto $10 \%$ polyacrylamide gels with SDS and transferred onto polyvinylidene fluoride (PVDF) membranes. Blocking and probing were performed in $5 \%$ milk dissolved in $0.2 \%$ Tween- $20 \mathrm{PBS}$ at $4{ }^{\circ} \mathrm{C}$ ON. Blots were imaged by Odyssey CLx Imaging System by LI-COR Biosciences and analyzed in the Image Studio software Ver 5.2.

\section{Co-immunoprecipitation}

The following Co-Immunoprecipitation protocol [71] was followed with modifications with the NE- 
PER $^{\text {TM }}$ kit (Cat. \# 78833) by Invitrogen. $250 \mu \mathrm{g}$ of cytoplasmic protein, $100 \mu \mathrm{g}$ of nuclear protein, and $40 \mu \mathrm{L}$ of protein G Dynabeads (Cat. \# 10003D) were used per IP. $10 \%$ was removed before the immunoprecipitation (IP) for input measurements. Protein G Dynabeads were blocked with $0.5 \%$ BSA for $2 \mathrm{hrs}$ at $4{ }^{\circ} \mathrm{C}$ on a rotator. Primary antibodies against AR (Abcam Cat\# ab74272) conjugated to beads on a rotator overnight at $4^{\circ} \mathrm{C}$. The following day, IP was performed on a rotator overnight at $4^{\circ} \mathrm{C}$. Protein was eluted by incubation at $70^{\circ} \mathrm{C}$ for 10 minutes in $2 \mathrm{X}$ Licor protein loading dye with $100 \mathrm{mM}$ of DTT. Western blots were performed as described above. Antibodies used can be found in Supplementary Table 2.

\section{Chromatin immunoprecipitation (ChIP) qPCR}

Chromatin immunoprecipitation (ChIP) was carried out as previously described [72]. Antibodies used can be found in Supplementary Table 2.

\section{Luciferase gene reporter assay and site-directed mutagenesis}

gDNA regions of interest were amplified using primers referenced in Supplementary Table 1. Gene specific primers included both MluI and BglII sites on flanking sides for cloning. Amplicons were cloned into Promega's pGL3 basic vector. Site-directed mutagenesis was carried out using primers indicated in Supplementary Table 1 with the Q5 ${ }^{\circledR}$ Site-Directed Mutagenesis Kit. Transfections were $10 \%$ pCMV- $\beta$-Gal for normalization. 6 hrs post transfection, cells were to CSS media for 18 hrs before DHT treatment for $48 \mathrm{hrs}$. Cells were lysed with $100 \mu \mathrm{L} 1 \mathrm{X}$ passive lysis buffer. Luciferase assay (Cat. \# E2620) and $\beta$-Galactosidase Enzyme assay (Cat. \# E2000) were performed per the manufacturer's protocol using a Perkin Elmer Wallac 1420 VICTOR $^{3^{\mathrm{TM}}}$ and Biotek $\mu$ Quant $^{\mathrm{TM}}$ 96-well Microplate Spectrophotometer.

\section{Statistical analysis}

Statistical significance of differences between the treatment groups was determined by an analysis of variance (ANOVA) or Student's $t$ test where applicable, and standard deviation was plotted as error bars. Levels of probability were noted. ${ }^{*}=p<0.05 ;{ }^{* *}=p<0.01 ;{ }^{* * *}=p<$ $0.005 ;{ }^{* * * *}=p<0.0001$.

\section{Abbreviations}

ADT: Androgen Deprivation Therapy; AR: Androgen Receptor; ANOVA: analysis of variance; ChIP: Chromatin Immunoprecipitation; CRPC: Castration Resistant Prostate Cancer; DHT: Dihydrotestosterone; GPER1: G-Protein Estrogen Receptor 1; IP: Immunoprecipitation; PCa:
Prostate Cancer; PSA: Prostate Specific antigen; TF: Transcription Factor; TSS: Transcription Start Site; WT: Wild Type.

\section{Author contributions}

The authors confirm contribution to the paper as follows: study conception and design: AM, YKL, KK, $\mathrm{SMH}$; data collection: AM; analysis and interpretation of results: AM, YKL, KK, SK and SMH; draft manuscript preparation: AM, YKL, KK and SMH. All authors reviewed the results and approved the final version of the manuscript.

\section{ACKNOWLEDGMENTS}

We gratefully thank Drs. Ying Xia and Divaker Choubey for their study design contributions.

\section{CONFLICTS OF INTEREST}

The authors declare that there are no conflicts of interest that could be perceived as prejudicing the impartiality of the research reported.

\section{FUNDING}

We sincerely acknowledge the financial support from VA Merit Awards I01BX000675 (S.M.H/Y.K.L.) and I01BX005395 (S.M.H/Y.K.L.) and NIH NIEHS training grant T32ES007250 (A.M.).

\section{REFERENCES}

1. Aurilio G, Cimadamore A, Mazzucchelli R, Lopez-Beltran A, Verri E, Scarpelli M, Massari F, Cheng L, Santoni M, Montironi R. Androgen Receptor Signaling Pathway in Prostate Cancer: From Genetics to Clinical Applications. Cells. 2020; 9:2653. https://doi.org/10.3390/cells9122653. [PubMed]

2. Snow O, Lallous N, Singh K, Lack N, Rennie P, Cherkasov A. Androgen receptor plasticity and its implications for prostate cancer therapy. Cancer Treat Rev. 2019; 81:101871. https://doi.org/10.1016/j.ctrv.2019.05.001. [PubMed]

3. Jillson LK, Yette GA, Laajala TD, Tilley WD, Costello JC, Cramer SD. Androgen Receptor Signaling in Prostate Cancer Genomic Subtypes. Cancers (Basel). 2021; 13:3272. https://doi.org/10.3390/cancers13133272. [PubMed]

4. Sun Y, Wang BE, Leong KG, Yue P, Li L, Jhunjhunwala S, Chen D, Seo K, Modrusan Z, Gao WQ, Settleman J, Johnson L. Androgen deprivation causes epithelial-mesenchymal transition in the prostate: implications for androgendeprivation therapy. Cancer Res. 2012; 72:527-36. https:// doi.org/10.1158/0008-5472.CAN-11-3004. [PubMed] 
5. Tan M, Xu J, Siddiqui J, Feng F, Sun Y. Depletion of SAG/ RBX2 E3 ubiquitin ligase suppresses prostate tumorigenesis via inactivation of the PI3K/AKT/mTOR axis. Mol Cancer. 2016; 15:81. https://doi.org/10.1186/s12943-016-0567-6. [PubMed]

6. Wu L, Runkle C, Jin HJ, Yu J, Li J, Yang X, Kuzel T, Lee C, $\mathrm{Yu}$ J. CCN3/NOV gene expression in human prostate cancer is directly suppressed by the androgen receptor. Oncogene. 2014; 33:504-13. https://doi.org/10.1038/onc.2012.602. [PubMed]

7. Liu YN, Liu Y, Lee HJ, Hsu YH, Chen JH. Activated androgen receptor downregulates E-cadherin gene expression and promotes tumor metastasis. Mol Cell Biol. 2008; 28:7096-108. https://doi.org/10.1128/MCB.0044908. [PubMed]

8. Lanzino M, Sisci D, Morelli C, Garofalo C, Catalano S, Casaburi I, Capparelli C, Giordano C, Giordano F, Maggiolini M, Andò S. Inhibition of cyclin D1 expression by androgen receptor in breast cancer cells--identification of a novel androgen response element. Nucleic Acids Res. 2010; 38:5351-65. https://doi.org/10.1093/nar/gkq278. [PubMed]

9. Li Y, Zhang DY, Ren Q, Ye F, Zhao X, Daniels G, Wu $\mathrm{X}$, Dynlacht B, Lee P. Regulation of a novel androgen receptor target gene, the cyclin B1 gene, through androgendependent E2F family member switching. Mol Cell Biol. 2012; 32:2454-66. https://doi.org/10.1128/MCB.06663-11. [PubMed]

10. Moehren U, Papaioannou M, Reeb CA, Grasselli A, Nanni S, Asim M, Roell D, Prade I, Farsetti A, Baniahmad A. Wild-type but not mutant androgen receptor inhibits expression of the hTERT telomerase subunit: a novel role of AR mutation for prostate cancer development. FASEB J. 2008; 22:1258-67. https://doi.org/10.1096/fj.07-9360com. [PubMed]

11. Huggins $C$, Hodges CV. Studies on prostatic cancer i. the effect of castration, of estrogen and of androgen injection on serum phosphatases in metastatic carcinoma of the prostate. Cancer Res. 1941; 1:293-97.

12. Lester JF, Mason MD. Cardiovascular effects of hormone therapy for prostate cancer. Drug Healthc Patient Saf. 2015; 7:129-38. https://doi.org/10.2147/DHPS.S50549. [PubMed]

13. Langley RE, Cafferty FH, Alhasso AA, Rosen SD, Sundaram SK, Freeman SC, Pollock P, Jinks RC, Godsland IF, Kockelbergh R, Clarke NW, Kynaston HG, Parmar MK, Abel PD. Cardiovascular outcomes in patients with locally advanced and metastatic prostate cancer treated with luteinising-hormone-releasing-hormone agonists or transdermal oestrogen: the randomised, phase $2 \mathrm{MRC}$ PATCH trial (PR09). Lancet Oncol. 2013; 14:306-16. https://doi.org/10.1016/S1470-2045(13)70025-1. [PubMed]

14. Moorthy HK, Laxman Prabhu GG, Venugopal P. The resurgence of estrogens in the treatment of castrationresistant prostate cancer. Indian J Urol. 2019; 35:189-96. https://doi.org/10.4103/iju.IJU 56 19. [PubMed]
15. Malkowicz SB. The role of diethylstilbestrol in the treatment of prostate cancer. Urology. 2001 (Suppl 1); 58:108-13. https://doi.org/10.1016/s0090-4295(01)012523. [ PubMed]

16. Ali A, Khalil MAI, Khan N, Abu Bakar M, Amjad A, Ahmed I, Mir K. Diethylstilbestrol in the Treatment of Castration-resistant Prostate Cancer: A Lower-middleincome Country Experience. Cureus. 2019; 11:e4470. https://doi.org/10.7759/cureus.4470. [PubMed]

17. Lam HM, Ouyang B, Chen J, Ying J, Wang J, Wu CL, Jia L, Medvedovic M, Vessella RL, Ho SM. Targeting GPR30 with G-1: a new therapeutic target for castration-resistant prostate cancer. Endocr Relat Cancer. 2014; 21:903-14. https://doi.org/10.1530/ERC-14-0402. [PubMed]

18. Migliaccio A, Castoria G, Auricchio F. Analysis of androgen receptor rapid actions in cellular signaling pathways: receptor/Src association. Methods Mol Biol. 2011; 776:361-70. https://doi.org/10.1007/978-1-61779-2434_21. [PubMed]

19. Nelius T, Filleur S, Yemelyanov A, Budunova I, Shroff E, Mirochnik Y, Aurora A, Veliceasa D, Xiao W, Wang Z, Volpert OV. Androgen receptor targets NFkappaB and TSP1 to suppress prostate tumor growth in vivo. Int $\mathrm{J}$ Cancer. 2007; 121:999-1008. https://doi.org/10.1002/ijc.22802. [PubMed]

20. Kim J, Lee Y, Lu X, Song B, Fong KW, Cao Q, Licht JD, Zhao JC, Yu J. Polycomb- and Methylation-Independent Roles of EZH2 as a Transcription Activator. Cell Rep. 2018; 25:2808-20.e4. https://doi.org/10.1016/j. celrep.2018.11.035. [PubMed]

21. Cai C, He HH, Chen S, Coleman I, Wang H, Fang Z, Chen S, Nelson PS, Liu XS, Brown M, Balk SP. Androgen receptor gene expression in prostate cancer is directly suppressed by the androgen receptor through recruitment of lysine-specific demethylase 1. Cancer Cell. 2011; 20:45771. https://doi.org/10.1016/j.ccr.2011.09.001. [PubMed]

22. van der Deen M, Akech J, Wang T, FitzGerald TJ, Altieri DC, Languino LR, Lian JB, van Wijnen AJ, Stein JL, Stein GS. The cancer-related Runx 2 protein enhances cell growth and responses to androgen and TGFbeta in prostate cancer cells. J Cell Biochem. 2010; 109:828. https://doi. org/10.1002/jcb.22463. [PubMed]

23. Jorgensen JS, Nilson JH. AR suppresses transcription of the LHbeta subunit by interacting with steroidogenic factor-1. Mol Endocrinol. 2001; 15:1505-16. https://doi.org/10.1210/ mend.15.9.0691. [PubMed]

24. Jorgensen JS, Nilson JH. AR suppresses transcription of the alpha glycoprotein hormone subunit gene through proteinprotein interactions with cJun and activation transcription factor 2. Mol Endocrinol. 2001; 15:1496-504. https://doi. org $/ 10.1210 /$ mend.15.9.0690. [PubMed]

25. Chipuk JE, Cornelius SC, Pultz NJ, Jorgensen JS, Bonham MJ, Kim SJ, Danielpour D. The androgen receptor represses transforming growth factor-beta signaling through 
interaction with Smad3. J Biol Chem. 2002; 277:1240-48. https://doi.org/10.1074/jbc.m108855200. [PubMed]

26. Shin T, Sumiyoshi H, Matsuo N, Satoh F, Nomura Y, Mimata H, Yoshioka H. Sp1 and Sp3 transcription factors upregulate the proximal promoter of the human prostatespecific antigen gene in prostate cancer cells. Arch Biochem Biophys. 2005; 435:291-302. https://doi.org/10.1016/j. abb.2005.01.002. [PubMed]

27. Verras M, Lee J, Xue H, Li TH, Wang Y, Sun Z. The androgen receptor negatively regulates the expression of c-Met: implications for a novel mechanism of prostate cancer progression. Cancer Res. 2007; 67:967-75. https:// doi.org/10.1158/0008-5472.CAN-06-3552. [PubMed]

28. Song K, Wang H, Krebs TL, Kim SJ, Danielpour D. Androgenic control of transforming growth factor-beta signaling in prostate epithelial cells through transcriptional suppression of transforming growth factor-beta receptor II. Cancer Res. 2008; 68:8173-82. https://doi. org/10.1158/0008-5472.CAN-08-2290. [PubMed]

29. Curtin D, Jenkins S, Farmer N, Anderson AC, Haisenleder DJ, Rissman E, Wilson EM, Shupnik MA. Androgen suppression of GnRH-stimulated rat LHbeta gene transcription occurs through Sp1 sites in the distal GnRHresponsive promoter region. Mol Endocrinol. 2001; 15:190617. https://doi.org/10.1210/mend.15.11.0723. [PubMed]

30. Lu S, Jenster G, Epner DE. Androgen induction of cyclindependent kinase inhibitor p21 gene: role of androgen receptor and transcription factor $\mathrm{Sp} 1$ complex. Mol Endocrinol. 2000; 14:753-60. https://doi.org/10.1210/ mend.14.5.0461. [PubMed]

31. Liu C, Wang C, Wang K, Liu L, Shen Q, Yan K, Sun X, Chen J, Liu J, Ren H, Liu H, Xu Z, Hu S, et al. SMYD3 as an oncogenic driver in prostate cancer by stimulation of androgen receptor transcription. J Natl Cancer Inst. 2013; 105:1719-28. https://doi.org/10.1093/jnci/djt304. [PubMed]

32. Grosse A, Bartsch S, Baniahmad A. Androgen receptormediated gene repression. Mol Cell Endocrinol. 2012; 352:46-56. https://doi.org/10.1016/j.mce.2011.06.032. [PubMed]

33. O'Connor L, Gilmour J, Bonifer C. The Role of the Ubiquitously Expressed Transcription Factor Sp1 in Tissuespecific Transcriptional Regulation and in Disease. Yale J Biol Med. 2016; 89:513-25. [PubMed]

34. Gartel AL, Radhakrishnan SK. Lost in transcription: p21 repression, mechanisms, and consequences. Cancer Res. 2005; 65:3980-85. https://doi.org/10.1158/0008-5472. CAN-04-3995. [PubMed]

35. Song J, Ugai H, Kanazawa I, Sun K, Yokoyama KK. Independent repression of a GC-rich housekeeping gene by Sp1 and MAZ involves the same cis-elements. J Biol Chem. 2001; 276:19897-904. https://doi.org/10.1074/jbc. M010658200. [PubMed]

36. Won J, Yim J, Kim TK. Sp1 and Sp3 recruit histone deacetylase to repress transcription of human telomerase reverse transcriptase (hTERT) promoter in normal human somatic cells. J Biol Chem. 2002; 277:38230-38. https:// doi.org/10.1074/jbc.M206064200. [PubMed]

37. Yuan H, Gong A, Young CY. Involvement of transcription factor $\mathrm{Sp} 1$ in quercetin-mediated inhibitory effect on the androgen receptor in human prostate cancer cells. Carcinogenesis. 2005; 26:793-801. https://doi.org/10.1093/ carcin/bgi021. [PubMed]

38. Hagen G, Müller S, Beato M, Suske G. Cloning by recognition site screening of two novel GT box binding proteins: a family of Sp1 related genes. Nucleic Acids Res. 1992; 20:5519-25. https://doi.org/10.1093/nar/20.21.5519. [PubMed]

39. Hagen G, Müller S, Beato M, Suske G. Sp1-mediated transcriptional activation is repressed by $\mathrm{Sp} 3$. EMBO J. 1994; 13:3843-51. [ubMed]

40. Huang Y, Shen P, Chen X, Chen Z, Zhao T, Chen N, Gong J, Nie L, Xu M, Li X, Zeng H, Zhou Q. Transcriptional regulation of BNIP3 by Sp3 in prostate cancer. Prostate. 2015; 75:1556-67. https://doi.org/10.1002/pros.23029. [PubMed]

41. Bouwman P, Philipsen S. Regulation of the activity of Sp1-related transcription factors. Mol Cell Endocrinol. 2002; 195:27-38. https://doi.org/10.1016/s0303-7207(02)00221-6. [PubMed]

42. Kadonaga JT, Carner KR, Masiarz FR, Tjian R. Isolation of cDNA encoding transcription factor $\mathrm{Sp} 1$ and functional analysis of the DNA binding domain. Cell. 1987; 51:1079-90. https://doi.org/10.1016/0092-8674(87)90594-0. [PubMed]

43. Philipsen S, Suske G. A tale of three fingers: the family of mammalian $\mathrm{Sp} / \mathrm{XKLF}$ transcription factors. Nucleic Acids Res. 1999; 27:2991-3000. https://doi.org/10.1093/ nar/27.15.2991. [PubMed]

44. Chintharlapalli S, Papineni S, Ramaiah SK, Safe S. Betulinic acid inhibits prostate cancer growth through inhibition of specificity protein transcription factors. Cancer Res. 2007; 67:2816-23. https://doi.org/10.1158/0008-5472. CAN-06-3735. [ [PubMed]

45. Hagen G, Dennig J, Preiss A, Beato M, Suske G. Functional analyses of the transcription factor $\mathrm{Sp} 4$ reveal properties distinct from Sp1 and Sp3. J Biol Chem. 1995; 270:2498994. https://doi.org/10.1074/jbc.270.42.24989. [PubMed]

46. Sapetschnig A, Koch F, Rischitor G, Mennenga T, Suske G. Complexity of translationally controlled transcription factor Sp3 isoform expression. J Biol Chem. 2004; 279:42095-105. https://doi.org/10.1074/jbc.M404989200. [PubMed]

47. Li L, Davie JR. The role of Sp1 and Sp3 in normal and cancer cell biology. Ann Anat. 2010; 192:275-83. https:// doi.org/10.1016/j.aanat.2010.07.010. [PubMed]

48. Hedrick E, Cheng Y, Jin UH, Kim K, Safe S. Specificity protein (Sp) transcription factors $\mathrm{Sp} 1, \mathrm{Sp} 3$ and $\mathrm{Sp} 4$ are non-oncogene addiction genes in cancer cells. Oncotarget. 2016; 7:22245-56. https://doi.org/10.18632/oncotarget.7925. [PubMed] 
49. Bedolla RG, Gong J, Prihoda TJ, Yeh IT, Thompson IM, Ghosh R, Kumar AP. Predictive value of Sp1/Sp3/FLIP signature for prostate cancer recurrence. PLoS One. 2012; 7:e44917. https://doi.org/10.1371/journal.pone.0044917. [PubMed]

50. Bigger CB, Melnikova IN, Gardner PD. Sp1 and Sp3 regulate expression of the neuronal nicotinic acetylcholine receptor beta4 subunit gene. J Biol Chem. 1997; 272:25976-82. https://doi.org/10.1074/jbc.272.41.25976. [PubMed]

51. Netzker R, Weigert C, Brand K. Role of the stimulatory proteins $\mathrm{Sp} 1$ and $\mathrm{Sp} 3$ in the regulation of transcription of the rat pyruvate kinase M gene. Eur J Biochem. 1997; 245:174 81. https://doi.org/10.1111/j.1432-1033.1997.00174.x. [PubMed]

52. Ward SV, Samuel CE. The PKR kinase promoter binds both $\mathrm{Sp} 1$ and $\mathrm{Sp} 3$, but only Sp3 functions as part of the interferon-inducible complex with ISGF-3 proteins. Virology. 2003; 313:553-66. https://doi.org/10.1016/s00426822(03)00347-7. [PubMed]

53. Dokmanovic M, Marks PA. Prospects: histone deacetylase inhibitors. J Cell Biochem. 2005; 96:293-304. https://doi. org/10.1002/jcb.20532. [PubMed]

54. Drummond DC, Noble CO, Kirpotin DB, Guo Z, Scott GK, Benz CC. Clinical development of histone deacetylase inhibitors as anticancer agents. Annu Rev Pharmacol Toxicol. 2005; 45:495-528. https://doi.org/10.1146/annurev. pharmtox.45.120403.095825. [PubMed]

55. Jaiswal AS, Balusu R, Narayan S. 7,12-Dimethylbenzanthracene-dependent transcriptional regulation of adenomatous polyposis coli (APC) gene expression in normal breast epithelial cells is mediated by GC-box binding protein Sp3. Carcinogenesis. 2006; 27:252-61. https://doi.org/10.1093/carcin/bgi225. [PubMed]

56. Yu B, Datta PK, Bagchi S. Stability of the Sp3-DNA complex is promoter-specific: Sp3 efficiently competes with $\mathrm{Sp} 1$ for binding to promoters containing multiple $\mathrm{Sp}$ sites. Nucleic Acids Res. 2003; 31:5368-76. https://doi. org/10.1093/nar/gkg706. [PubMed]

57. Gilmour J, O'Connor L, Middleton CP, Keane P, Gillemans N, Cazier JB, Philipsen S, Bonifer C. Robust hematopoietic specification requires the ubiquitous $\mathrm{Sp} 1$ and $\mathrm{Sp} 3$ transcription factors. Epigenetics Chromatin. 2019; 12:33. https://doi.org/10.1186/s13072-019-0282-9. [PubMed]

58. Stoner M, Wormke M, Saville B, Samudio I, Qin C, Abdelrahim M, Safe S. Estrogen regulation of vascular endothelial growth factor gene expression in ZR-75 breast cancer cells through interaction of estrogen receptor alpha and SP proteins. Oncogene. 2004; 23:1052-63. https://doi. org/10.1038/sj.onc.1207201. [PubMed]

59. He S, Sun JM, Li L, Davie JR. Differential intranuclear organization of transcription factors Sp1 and Sp3. Mol Biol Cell. 2005; 16:4073-83. https://doi.org/10.1091/mbc.e0505-0388. [PubMed]
60. He S, Davie JR. Sp1 and Sp3 foci distribution throughout mitosis. J Cell Sci. 2006; 119:1063-70. https://doi. org/10.1242/jcs.02829. [PubMed]

61. Diao X, Chen X, Pi Y, Zhang Y, Wang F, Liu P, Gao Y, Wang X, Yang S, Lu S. Androgen receptor induces EPHA3 expression by interacting with transcription factor SP1. Oncol Rep. 2018; 40:1174-84. https://doi.org/10.3892/ or.2018.6503. [PubMed]

62. De Marco P, Romeo E, Vivacqua A, Malaguarnera R, Abonante S, Romeo F, Pezzi V, Belfiore A, Maggiolini M. GPER1 is regulated by insulin in cancer cells and cancerassociated fibroblasts. Endocr Relat Cancer. 2014; $21: 739$ 53. https://doi.org/10.1530/ERC-14-0245. [PubMed]

63. Pal SK, Patel J, He M, Foulk B, Kraft K, Smirnov DA, Twardowski P, Kortylewski M, Bhargava V, Jones JO. Identification of mechanisms of resistance to treatment with abiraterone acetate or enzalutamide in patients with castration-resistant prostate cancer (CRPC). Cancer. 2018; 124:1216-24. https://doi.org/10.1002/cncr.31161. [PubMed]

64. Han GC, Hwang J, Wankowicz SAM, Zhang Z, Liu D, Cibulskis C, Gaviola GC, Ghazikhanian V, McKay RR, Bubley GJ, Carter SL, Balk SP, Hahn WC, et al. Genomic Resistance Patterns to Second-Generation Androgen Blockade in Paired Tumor Biopsies of Metastatic Castration-Resistant Prostate Cancer. JCO Precis Oncol. 2017; 1:PO.17.00140. https://doi.org/10.1200/PO.17.00140. [PubMed]

65. Kanno Y, Zhao S, Yamashita N, Yanai K, Nemoto K, Inouye $\mathrm{Y}$. Androgen receptor functions as a negative transcriptional regulator of DEPTOR, mTOR inhibitor. J Toxicol Sci. 2015; 40:753-58. https://doi.org/10.2131/ its.40.753. [PubMed]

66. Tu WH, Zhu C, Clark C, Christensen JG, Sun Z. Efficacy of c-Met inhibitor for advanced prostate cancer. BMC Cancer. 2010; 10:556. https://doi.org/10.1186/1471-2407-10-556. [PubMed]

67. Varkaris A, Corn PG, Gaur S, Dayyani F, Logothetis CJ, Gallick GE. The role of $\mathrm{HGF} / \mathrm{c}-$ Met signaling in prostate cancer progression and c-Met inhibitors in clinical trials. Expert Opin Investig Drugs. 2011; 20:1677-84. https://doi. org/10.1517/13543784.2011.631523. [PubMed]

68. Chan QK, Lam HM, Ng CF, Lee AY, Chan ES, Ng HK, Ho SM, Lau KM. Activation of GPR30 inhibits the growth of prostate cancer cells through sustained activation of Erk1/2, $\mathrm{c}$-jun/c-fos-dependent upregulation of p21, and induction of G(2) cell-cycle arrest. Cell Death Differ. 2010; 17:1511-23. https://doi.org/10.1038/cdd.2010.20. [PubMed]

69. Ho SM, Rao R, To S, Schoch E, Tarapore P. Bisphenol A and its analogues disrupt centrosome cycle and microtubule dynamics in prostate cancer. Endocr Relat Cancer. 2017; 24:83-96. https://doi.org/10.1530/ERC-16-0175. [PubMed]

70. Roberts TC, Hart JR, Kaikkonen MU, Weinberg MS, Vogt PK, Morris KV. Quantification of nascent transcription by bromouridine immunocapture nuclear run-on RT-qPCR. 
Nat Protoc. 2015; 10:1198-211. https://doi.org/10.1038/ nprot.2015.076. [PubMed]

71. Zhu X, Zelmer A, Wellmann S. Visualization of Proteinprotein Interaction in Nuclear and Cytoplasmic Fractions by Co-immunoprecipitation and In Situ Proximity Ligation Assay. J Vis Exp. 2017; 55218. https://doi. org/10.3791/55218. [PubMed]
72. Decker KF, Zheng D, He Y, Bowman T, Edwards JR, Jia L. Persistent androgen receptor-mediated transcription in castration-resistant prostate cancer under androgen-deprived conditions. Nucleic Acids Res. 2012; 40:10765-79. https:// doi.org/10.1093/nar/gks888. [PubMed] 